\title{
Conclusion
}

\section{Sacrificed Children of the Republic?}

Heard about the guy who fell off a skyscraper? On his way down past each floor, he kept trying to reassure himself: "So far, so good... So far, so good.... So far, so good." How you fall doesn't matter. It's how you land.

-FROM LA HAINE, A FILM BY MATHIEU KASSOVITZ

"Rwanda has nothing to do with race, so I'm told. Discrimination against Koreans in Japan has nothing to do with race, so I'm told. The very long struggle of the Irish in Great Britain is not about race, so I'm told. Maybe. But when is racism ever about race, pure and simple; when is religious persecution ever simply about religion; when is patriotism ever about defending the nation-state; when is misogyny nothing more than an uncontrollable and inexplicable hatred of women; when is tribalism ever merely one tribe fighting another tribe because, well, they're another tribe? The question, therefore, is not whether race matters but how it matters. How does it shape, sustain, and define systems of domination? How has it functioned in different times and places?"

-ROBIN KELLEY, "RACE AND RACISM: A SYMposium"

In 2009, in a radio debate on national identity, Nadine Morano, a Les Républicains party politician, said: "We're not putting young Muslims on trial. I respect their situation. What I want for them is to feel French because they are French. I want them to love France when they live here, to find work, and to not speak in slang. They shouldn't put their caps on back to front" (Leveque et al. 2009).

Recent events in France show that Muslims, and maghrébin-origin individuals more generally, are on trial.

On January 7, 2015, the brothers Said and Chérif Kouachi massacred twelve people in the eleventh arrondissement offices of the weekly satirical magazine Charlie Hebdo. Hundreds of thousands gathered at the Place de la République that 
evening for a spontaneous demonstration. President François Hollande declared the following day, January $8,{ }^{1}$ a national day of mourning. On January 9, Amedy Coulibaly took hostages in a Hyper Cacher kosher supermarket near Porte de Vincennes and killed four people. The Kouachi brothers, born in Paris to Algerian immigrant parents, and Coulibaly, born in the southeastern banlieue of Juvisysur-Orge to Malian immigrants, had ties to Islamic extremism.

In the aftermath of the killings, attention focused on the slain cartoonists and the columnists, and the rallying cry "Je suis Charlie" sprang up. A different cry soon appeared, in recognition of another victim of the attacks: Ahmed Merabet. Merabet, a Muslim police officer of Algerian origin, was killed while trying to pursue the Kouachi brothers. But the cry of "Je suis Ahmed" was far less common. Instead, French Muslims were subjected to "collective punishment" (Hajjat 2015), and many, among them my respondents, were asked to denounce violence they had nothing to do with. In the wake of the massacre at Charlie Hebdo headquarters, France witnessed more than 128 anti-Muslim attacks. Several supporters of the massacre were arrested as "apologists for terrorism," including the comedian M’Bala M'Bala, known professionally as Dieudonné, who joked on Facebook, "I feel like Charlie Coulibaly."

Later that year, in November, another series of coordinated terrorist acts, also linked to Islam extremism, occurred at several sites in the Parisian metropolitan region, including the Stade de France, in Seine-Saint-Denis; the Bataclan theater in the eleventh arrondissement; and La Belle Équipe and several restaurants and cafés near the Canal Saint-Martin. Among the more than 130 people killed, there were several maghrébin-origin individuals. Following the attacks, President Hollande proposed stripping dual citizens convicted of terrorism of their French citizenship (a proposal withdrawn several months later amid opposition). Hollande declared a state of emergency that lasted several months, allowing police to conduct raids without warrants, among other measures. ${ }^{3}$ Heightened Islamophobia ensued.

On July 14, Bastille Day, 2016, Mohamed Lahouaiej Bouhlel, a thirty-one-yearold born in Tunisia who moved to France in 2005, drove a truck through a crowd gathered to watch the fireworks in Nice, in southern France, killing eighty-four people and injuring more than three hundred. The Islamic State claimed responsibility for the attack, and the French government declared it a terrorist incident. The incident raised additional concern about whether Muslims could be successfully incorporated into French society. ${ }^{4}$

The summer of 2016 also saw the controversial ban on the burkini, the full-body swimsuit covering everything except for the face, worn by some Muslim women. Several French towns banned it, and photos of Muslim women on beaches who were fined and forced to remove their suits flooded the news and social media. Then-Prime Minister Manuel Valls referred to the burkini as a form of enslavement. The ban in the French Rivera town of Villeneuve-Loubet was overturned as 
a violation of civil liberties. Yet opposition to the burkini-on the argument that its presence challenges French values-remains. ${ }^{5}$

These events illustrate the implications of the denial of cultural citizenship to racial and ethnic minorities in French society and are only a sampling of many similar incidents. They sparked concerns about the presence of Muslims in France and their perceived incompatibility with Western society, but the role of race and ethnicity as markers of difference was rarely mentioned. Islamophobia is not just about Islam; it is also about racism. Even North African--origin individuals who do not identify as practicing Muslims nonetheless feel marginalized because of their North African origins, because they are nonwhite. They are treated as though they are not French, even if they identify as such. Even though France espouses a colorblind Republican ideology, race and ethnicity are very much present in the lives of non-white minorities.

I chose the title Citizen Outsider because the middle-class North African second generation qualifies as both. Its members are simultaneously part of French society and separate from it. They cannot fully belong to it because of their maghrébin origins and their connection to France's colonial history. Contemporary France cannot see them as having French origins, only North African ones. If France continues to ignore the experiences of those on the margins of society, violent incidents like those I describe above will continue to occur. She ignores her minorities at her own peril.

I have been fascinated with and curious about the politics of identity, race, and ethnicity in France for well over a decade, beginning with my first trip to Paris. I originally sought to understand what it is like to be an ethnic minority in France, and how it contrasts with the experiences of ethnic minorities in the United States. As I planned the dissertation research that later served as the basis for this book, many people-both French and American-told me, or perhaps warned me, that race and racism were dramatically different in the two countries. In France differences between children of maghrébin-origin immigrants and whites are based on religion (Islam versus Christianity), socioeconomic status, and culture. As the adage goes, "Some people just don't want to be French."

I originally thought France would be dramatically different from the United States-based in part on the history of black American expatriates there. Yet, as I have demonstrated, the experience of minorities in France is not as different as one might expect-not only of how immigrants and their descendants fare but also in how people of different races and ethnic origins are treated. France, like the United States and other pluralistic societies, is a work in progress. As the experiences of these respondents reveal, race and racism are central to their lives. And they take precedence over citizenship and socioeconomic status.

In this book, I have shown that ethnic minorities in France, even as citizens, remain on the margins of mainstream society, which underlines the salience of 


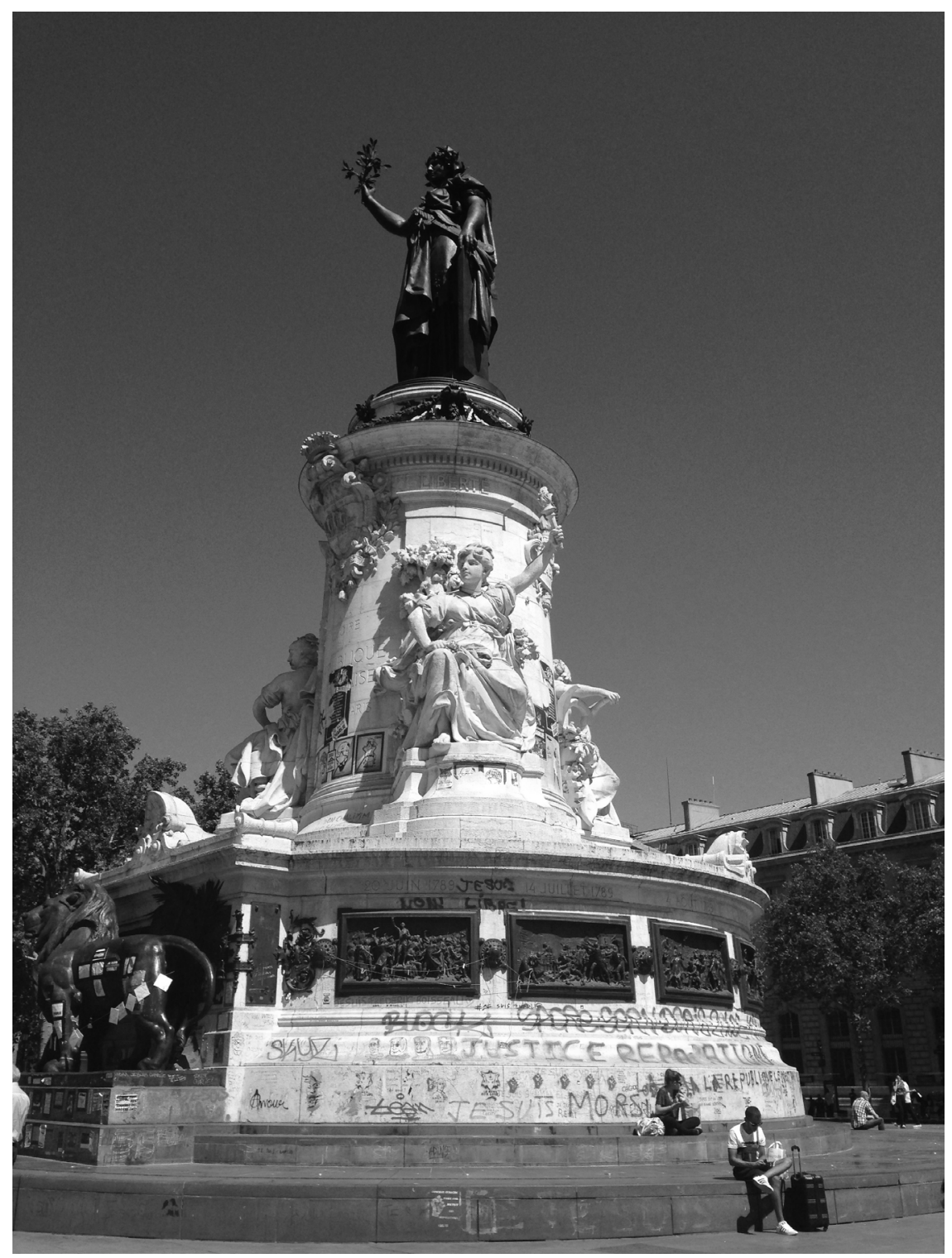

Figure 3. Place de la République. Photo by author. 
race and ethnicity. The marginalization of children of North African immigrants persists despite their trajectories of mobility and attainment of middle-class status. They are denied cultural citizenship because they are maghrébin, or nonwhite. The implicit and explicit racial and ethnic boundaries that define French identity keep the North African second generation from successfully asserting it. Its members remain vulnerable in a society that refuses to acknowledge them as French.

\section{WHAT DOES THE NORTH AFRICAN SECOND GENERATION WANT, AND WHY DOES IT MATTER?}

I have discussed respondents' experiences growing up in France with immigrant parents, and the dual cultural worlds children of maghrébin immigrants have had to navigate between France and the Maghreb. Respondents' place within French society was questioned at an early age, implicitly and explicitly. Explicitly, children of North African immigrants were told to "return to their country" or called ethnic slurs by neighbors and students. Implicitly, children of maghrébin immigrants were socialized through the French educational system and other state institutions that they were not a part of the definition of a French person. This is an example of how, from a young age, the North African second generation is denied cultural citizenship because they are of maghrébin origin. In chapter 3 , I discussed how this denial of cultural citizenship continues into adulthood for respondents, including in the workplace, religion, place and residential environment, and the public sphere. Even after this generation attains a middle-class status, they cannot escape being treated differently because of their racial and ethnic status. I also discussed the implications for how the North African second generation is expected to hide its difference, even when it cannot. After discussing how respondents are denied cultural citizenship and marginalized because they are non-white, I then discussed the impact of this on how the North African second generation self-identifies in chapter 4. Most respondents configure their identities in some way that references both being French and maghrébin. Yet they are only seen as maghrébin by others and not as French. Finally, in chapter 5, I discussed how respondents connect with black populations worldwide, including black Americans, and understand blackness more generally as they make sense of their social locations and experiences of marginalization.

Children of maghrébin immigrants are rejected despite belonging to France. They are staunch defenders of the Republican model but feel in their case it is not implemented correctly. They want all French citizens to be treated the same. They do not assert an oppositional identity or consciousness. They accept, rather than reject, France.

Safia, a thirty-two-year-old with dual Tunisian and French citizenship, describes this view: 
France confuses assimilation and integration, and that's a shame. Assimilation involves erasing. I don't want to erase my origins. I don't want to forget that my parents immigrated here from Tunisia, that I have a Muslim sensibility, that I have family that lives in Tunisia. Assimilation, it means that to be French I have to eat pork and drink alcohol. . . . But integration is understanding that I'm French regardless of those differences. And I would like people to stop asking me about my origins when they meet me for the first time. It's not the only thing that defines me. I'm reduced to my social origins, my ethnic origins. And that's the problem.

The maghrébin second generation wants to be viewed as French as any of their compatriots. Its members wish to belong in France and to be accepted as French. Its understanding of what it means to be of maghrébin origin and French is shaped by whites who deny its members their place in mainstream society. This informs the boundaries they draw around both maghrébin and French as identities. They wish to be recognized as part of the French Republic (Keaton 2010). The North African second generation desires "more integration" and "strongly supports the French model while they are perceived as threatening core Republican values" (d'Appollonia 2009, 283). They do not voluntarily reject Frenchness; Frenchness rejects them. The difference ascribed to immigrant-origin individuals is often framed as one of culture, religion, residential location, or citizenship status. But these are code words for race and ethnicity, as they know from their everyday interactions and interactions with social institutions.

\section{THE CONTINUING SIGNIFICANCE OF RACE AND ETHNICITY}

The year 2015 marked the tenth anniversary of the uprisings that spread through banlieues throughout France, following the deaths of two ethnic minority youths who were fleeing the police that fall. ${ }^{6}$ One respondent, Mourad, described to me the sentiment of many banlieue residents at the time: "You don't see me as a French person. OK, we're not French, so we're Muslim, Algerian, Moroccan, Tunisian. I'll wear a jacket with the Algerian flag on the back. . . . That transforms into aggression. That's what the riots in November 2005 were all about."

When I asked other respondents about the uprisings, they said pretty much the same thing. The frustrations of this often-ignored segment of the French population made the uprisings inevitable. The American media bemoaned the failure of France's Republican model to integrate its immigrants and minorities or fully address its colonial legacy. It brought attention to the "other France," the one not typically seen in tourism brochures and films about France accessible to American audiences. Within France, much of the media commentary subsequent to the uprisings characterized the individuals involved as unwilling to integrate into mainstream society, and rejecting its norms and values. On a French nightly 
news program, then-minister of the interior Nicolas Sarkozy insisted that the individuals involved in protests must learn to adapt to France. The implication, of course, was that they were too different to assimilate into the society in which they were born and raised and that change must come from them, not the state or French society. Protestors challenged this dominant narrative and began carrying signs stating, "Nous sommes tous les racailles" (We're all scum), reclaiming a pejorative term Sarkozy had used against them and demanding that France see them as French.

Many respondents said that uprisings of this sort would likely happen again, for they felt that little had changed. Ten years after their occurrence, the police officers involved in the deaths of Zyed Benna and Bouna Traoré were acquitted of all charges.' A Human Rights Watch (2012) report found that the majority of North African-origin and sub-Saharan-origin individuals said identity checks by the police were a major problem. They are six to eight times more likely than whites to undergo "pat-downs" (see also OSI 2009). The framing of immigrant-origin individuals as rejecting France does not fully explain the occurrence of the uprisings. Even when maghrébin-origin individuals do everything right, such as acquiring university degrees and working in a professional capacity, they are still excluded from mainstream society. If French society rejects racial and ethnic framing as a means to understand events like the 2005 banlieue uprisings, ethnic minorities know differently.

The experience of Zara, a twenty-eight-year-old of Moroccan origin, again demonstrates how the onus of integration falls on racial and ethnic minorities. Her Algerian aunt had been in an abusive relationship with a white man. Zara had told her repeatedly that he was not good for her, that something was wrong with him, and that she should leave him. But her aunt did not listen and Zara eventually lost touch with her. One day her aunt called her, crying, and asked Zara to help her and come pick her up because she did not feel well. Zara did and her aunt came to live with her. Her aunt told her how they had been arguing a lot. One morning, her aunt went downstairs to use a telephone booth, and soon afterward Zara heard her aunt shouting. Her abusive boyfriend had figured out where Zara lived. Wearing a nightgown, Zara ran outside to find the boyfriend shoving her aunt into his car. "I tried to stop it, but I didn't succeed," she explained. "He drove away with her."

Zara then went to the local police station to file a report against him. The officer said that the police would go to the boyfriend's house and bring him in. Though Zara asked the police to contact her after this took place, she heard nothing from them. She returned to the station later that day and learned that her aunt was in custody. The police had removed her aunt from the boyfriend's house and then took her with them. Zara started to complain to the officer, but he told her that the boyfriend had said it was Zara who was racist toward whites like him. "It's important that you integrate," the officer told her. 
The roles of Zara and the boyfriend had suddenly reversed. It was she who had become the problem; it was the boyfriend who complained. And it was Zara who needed to change. She remembers thinking that, had she been white, she would have been treated differently and the police officer probably would have taken her complaint seriously. In frustration, Zara said there was nothing she could do. A colorblind, Republican institution of the state had failed her.

In theory, the Republican model does not recognize race and ethnicity, does not want to reify differences that those terms imply. ${ }^{8}$ What is clear, however, is that the model is not working if a segment of France's population is marked as different and treated differently because it is nonwhite.

The French model for identity politics differs from that in the United States and many other societies. ${ }^{9}$ France essentially attempts to erase race and ethnicity from social life; by refusing to acknowledge such categories, they are deprived of meaning. The colorblind Republican model holds that race, ethnicity, and other distinctions related to identity produce identity politics, making race and ethnicity salient where they otherwise would not be. But as the experiences of these citizen outsiders show, individuals are still racialized even without state-sanctioned identity categories. The distinction between public and private spheres does not change this, for the differences drawn exist in both.

Boundaries around identity in France dictate who does and does not belong in French society. The North African second generation, and its middle-class segment, is repeatedly told it does not belong. In response to this marginalization, the second generation has formed a distinct community, and a distinct identity politics related to ethnic origins. Ironically, communautarisme, which is feared in France (Chabal 2015), has been recreated by the exclusion of children of maghrébin-origin immigrants and their desire to connect with others who share similar experiences.

Members of the North African second generation see themselves as racialized or ethnicized subjects. Their difference, or otherness, is an ascribed one and not an oppositional choice of their own. Race and ethnicity establish and reinforce their second-class citizenship and deny them cultural citizenship.

\section{CULTURAL CITIZENSHIP IN FRANCE AND BEYOND}

France's framework for addressing diversity and multiculturalism is assimilationist. Nonwhites are expected to assimilate into the mainstream; differences should be relegated to the private sphere. But the nation's colonial history and its unacknowledged racial and ethnic foundations deny a segment of its citizens the real and symbolic benefits that come with being part of the French nation. It is instructive to compare the French example with how other pluralistic societies deal with cultural, religious, and ethnic diversity. As Stephen Castles (1997) has noted, like 
France, the United Kingdom and the Netherlands have adopted an assimilationist model, the United States and Canada have opted for a pluralist model, and Germany practices differential exclusion. It comes as no surprise, then, that recent research has shown how newly immigrated women in London and Amsterdam feel like second-class citizens (Ghorashi and Vieten 2012). Citizenship is a marker of difference for these immigrants, as it for my respondents. For marginalized populations, it remains a continual negotiation, not something conferred on them by law.

Maghrébin-origin individuals are depicted as uniquely responsible for their own plight: They are said to not try hard enough to fit in, even if their socioeconomic status and professional attainments are the equal of whites. Rather than reject their societies, however, Maghrebin-origin individuals in France and other marginalized populations around the world are, instead, claiming their rightful places within their societies. As citizens, they see themselves as deserving of rights and privileges meant for all. We must imagine a citizenship and societal belonging in which racial, ethnic, cultural, and religious difference do not stand in the way of full societal inclusion. This is how we address the denial of cultural citizenship. By failing to accommodate differences in the public sphere, France loses out on a true and cohesive national community. France's emphasis on monoculturalism and universalism do not allow for this. And theories of immigrant integration and assimilation fail to capture the experiences of immigrant-origin racial and ethnic minorities.

The denial of cultural citizenship exists beyond France, as demonstrated by the Brexit vote, attributed in part to xenophobic sentiment; by the heightened Islamophobia and rise of the Far Right in European societies such as the Netherlands and Germany; and by the debate over how to respond to the Syrian refugee crisis in the European Union. In the United States, we can see the denial of cultural citizenship to African Americans, who even though they are legal citizens, are subject to disparate treatment, as evidenced by "stop and frisk" procedures and the phenomenon of "driving while black," among other examples. Or the case of Muslim Americans and immigrants who face heightened suspicion and Islamophobia, including Executive Order 13769 signed by President Donald Trump in January 2017 banning immigrants from various Muslim majority countries such as Iran, Syria, and Iraq. Our idea of who belongs in a given nation and who is seen as a full member of society is undergirded or circumscribed by race and ethnicity. This point is clear when we consider Ahmed Merabet, the Muslim and Algerianorigin police officer who was one of the victims of the massacre at the Charlie Hebdo editorial offices. He was just as French as the other victims. He had a stable middle-class job. He was a Muslim who fought to defend the French motto of Liberté, égalité, et fraternité yet is rarely mentioned in the news reports of the events. And while the cry of "Je suis Ahmed" was virtually ignored, "Je suis Charlie" was 
quickly adopted as an affirmation of French values. When we consider the lack of attention paid to the plight of the North African second generation and other racial and ethnic minorities, it is not hard to understand why.

That the struggle for full cultural citizenship is a global struggle is evident most recently in the death of Adama Traoré, a twenty-four-year-old black construction worker, who died under unusual circumstances after being arrested in the banlieue of Beaumont-sur-Oise, north of Paris. ${ }^{10} \mathrm{He}$ was arrested for interfering in the arrest of his brother. The police first claimed that he had died of a heart attack and then later said he had a severe infection. His family asked for a second autopsy because they say he had no health problems prior to his death. Since his death, there have been demonstrations demanding justice for Adama Traoré, including one protest outside the local police station, which was met with tear gas from the police. Part of the mobilization around justice for Traoré has been connected to struggles for black liberation in other societies, including the United States. The incidents of state-sponsored violence against black Americans are being closely followed by racial and ethnic minorities in France, who also seek to affirm their rightful place in society and challenge racial and ethnic marginalization. During my recent visits to France, I remain fascinated by the transnational connections racial and ethnic minorities are making-despite differences in their societies. Within Paris and its banlieues, there have even been demonstrations in honor of Mike Brown, Freddie Gray, and other black American victims of state-sponsored violence.

In titling this chapter "Sacrificed Children of the Republic,"11 I also want to consider what is at stake by denying cultural citizenship to racial and ethnic minorities. I return to Safia, whom I caught up with during a trip to Paris in 2015. She has achieved even more success as a journalist-now working as an editor in addition. As we met in her office in the fifteenth arrondissement, she recounted a recent disturbing incident. One day she traveled to Marseille (in the south of France) by train for some work-related meetings. She had no luggage with her since she was not spending the night and was carrying a satchel containing the items she needs for work. When Safia's train arrived at the Gare de Lyon at the end of the day, she was stopped leaving the train by a plainclothes police officer. He demanded to see what was inside her bag. She told me, "Il ma tutoyée," that is, he addressed her by using the informal, or familiar, pronoun $t u$ (you) rather than the formal vous, not merely a breach of etiquette but, in France, a clear sign of disrespect. Safia was offended by his use of the $t u$ form, and also because he did not immediately identify himself as a police officer. He demanded to see her identification and asked her why she was carrying only a satchel. "Are you smuggling drugs?" he asked. "Are you a prostitute, working for someone?" Humiliated, Safia answered that she was a journalist and had gone to Marseille for meetings. She showed him her carte d'identité and other identification issued by the publication for which she works. 
"The craziest thing," she told me, as her eyes welled up with tears, "was that the train was packed with people, white people. There were a ton of white people. And I was the one who was stopped. No one said a thing. The other passengers just stared at me." Safia is pursuing legal means to address this incident, which as she explained, she has seen happen to too many racial and ethnic minorities in France. "You just can't let these things go by," she said. "How can people not think this is wrong?" Though in many ways Safia, like other immigrants and their descendants, has done the things that should allow her to fit in-she has worked hard, attained an education, and holds a stable, middle-class job-what's clear is that these are not enough. She does not belong in France-because she is not white. 
